\title{
Estimating the impact of COVID-19 on the Spanish economy with input-output analysis
}

\author{
Eladio Febrero Paños / Fernando Bermejo Patón* \\ Universidad de Castilla-La Mancha, Departamento de Fundamentos del Análisis Económico, Avenida de los Alfares, 44, Edifi- \\ cio Gil de Albornoz, 16071 Cuenca, Spain
}

Received: 18 September 2020 / Accepted: 28 March 2021

\begin{abstract}
In this paper we present a forecast of the impact of measures to stem CoVID-19 on the Spanish economy at a highly disaggregate level, using input-output techniques. Our estimations cover the period 2020-2021, and we consider two scenarios depending on the possibility of a second wave of massive infections in the autumn of 2020. In 2020, the lockdown of the population and the shutdown of a large part of the production system for several weeks are a supply-side shock that will be followed by a demand-side shock whose impact is expected to be even larger. In 2021 there will be some recovery, although we believe that it will not be sufficient for offsetting the initial negative shock.
\end{abstract}

\section{Keywords}

COVID-19 / Spanish economy / Input-output analysis.

\section{Estimación do impacto da COVID-19 na economía española con táboas input-output}

\section{Resumo}

Neste artigo presentamos unha previsión do impacto das medidas para frear a COVID-19 na economía española a un alto nivel de desagregación sectorial, utilizando metodoloxía input-output. As nosas estimacións refírense ao período 2020-2021, no que consideramos dous escenarios en función da posibilidade dunha segunda vaga de infeccións masivas no outono de 2020. As medidas de confinamento da poboación e a paralización de gran parte do sistema produtivo durante varias semanas de 2020 supuxeron un shock de oferta ao que se unirá un shock de demanda cuxo impacto se espera que sexa aínda maior. En 2021 haberá certa recuperación, aínda que consideramos que non será o suficientemente intensa como para compensar o shock negativo inicial.

Palabras clave

COVID-19 / Sistema económico español / Análise input-output.

JEL Codes: E20, D57.

\section{Introduction}

COVID-19 is inflicting a lot of harm throughout the world. According to the World Health Organization (WHO, 2020), the virus has caused more than 1.3 million deaths, and roughly 60 million people have been infected. Without a vaccine, social distancing (along with mask wearing and frequent handwashing) has become a must to stop the spread. However, this measure, which was behind the great lockdown in March and April, plus the fear of contagion and uncertainty about how the situation will evolve in the near future, are causing a significant impact on economic activity and employment. And to make matters worse, this shock is taking place in the context of generally low economic growth -secular stagnation, according to Summers (2014)-, high levels of debt, extremely unequal income

* E. Febrero: eladio.febrero@uclm.es, F. Bermejo: fernando.bermejo@uclm.es (corresponding author). 
distribution, an aging population in advanced economies (Gordon, 2016) and serious hysteresis issues (Baldwin, 2020).

The International Monetary Fund (IMF, 2020b) has projected global growth of $-4.4 \%$ in 2020, with some Eurozone countries expected to be impacted well above the average in 2020: France's Gross Domestic Product (GDP) is predicted to fall by $9.8 \%$, Italy's by $10.6 \%$ and Spain's by $12.8 \%$. The impact on the Spanish economy is expected to be especially large, according to the IMF (2020a), due to the importance of the tourism sector, plus the scarcity of large firms and the large volume of temporary labor contracts.

The aim of this paper is to estimate the impact of COVID-19 on output and employment, at the sectoral level, for the Spanish economy in 2020 and 2021, using input-output techniques. Hence, the main takeaway from this paper provides a forecast with a higher degree of specificity than the one offered by official agencies, particularly on industries that will be highly affected by the pandemic (motor vehicles, accommodation and restaurants, transport, and relatively large industries heavily impacted by the decrease in resident agent consumption and exports). To that end, we combine the latest information on symmetric IO tables for the Spanish economy with published forecasts of final demand (Banco de España, 2020a, 2020d), and additional information provided by entrepreneurial associations (Asociación Española de Fabricantes de Automóviles y Camiones [ANFAC], Exceltur Alianza Turística [Exceltur], etcetera) and the Spanish Statistical Office known as Instituto Nacional de Estadística (INE), in order to disaggregate those shocks at the required sectoral level. Our purpose is to measure the direct and indirect consequences of the measures adopted to stop the spread of the virus at a high level of disaggregation (64 industries) ${ }^{1}$, before monetary and fiscal policies, or changes in labor market regulations, are adopted by economic authorities to fight the shock caused by the pandemic. We believe that this information may be useful, amongst other reasons, as a guide for the economic policy decisions that will offset the consequences of the pandemic (on this, see for instance Blanchard, Philippon \& Pisani-Ferry (2020)).

We have proceeded in two steps. Firstly, measures for containing the spread of the virus led to a supply-side shock, after the declaration of the state of alarm on March 14th, which led to restrictions on mobility and distance, and the closure of all non-essential activities from March 30th to April 9th2. This supply shock meant a loss of output and income because many businesses were forced to close (e.g. many firms in the manufacturing or service sectors) and/or work at a rather low degree of capacity for a period of time ranging between two weeks and nearly three months. During the harshest period of the lockdown, people were forced to stay at home, and later they were obliged to remain in the city/town where they live, thus affecting accommodation, the transportation of people, and the retail trade with the exception of food and pharmacies. Meanwhile, other industries had to adopt very different modes of operation (e.g. education).

Secondly, the supply shock was followed by a demand shock, as agent income fell and they began to spend a lower proportion of their earnings as a consequence of uncertainty about the evolution of the pandemic. We highlight the following four aspects, regarding final demand:

- Private consumption falls because the lockdown means a generalized decrease in value added pari passu with reduced output, resulting in less disposable income for households. The demand for some consumer goods (e.g. food) remains roughly stable during the supply-side shock, but for other goods it will stay at a lower level for a long period of time (e.g. many consumer durable goods and social entertainment).

-An additional drop in private consumption occurs because, in slumps, the propensity to consume falls as an understandable reaction to uncertainty.

\footnotetext{
${ }^{1}$ For the sake of simplicity, the results are shown at a disaggregated level in 15 sectors. Estimations for an additional 64 sectors are available upon request

2 See Real Decreto 463/2020 and Real Decreto-Ley 10/2020 and further extensions (Gobierno de España, 2020). The state of alarm was extended until June 21 .
} 
-Exports fall, especially in the tourism sector (accommodation, restaurants, entertainment and transport), with the decline taking place in a period of time that is different from that of the supplyside shock (the former mostly in the summer, whilst the latter took place in the spring).

- The corporate sector delays investment decisions if autonomous demand is expected to remain weak for a long period of time, as described by the accelerator theory of investment in Bortis \& Heinrich (1997), de-Juan (2005), Serrano (1995), among others.

Although for some industries the supply and demand shocks take place in different periods of time, we shall assume that, to some degree, their consequences overlap (i.e. some of the vehicles that consumers do not purchase, because of a fall in income or greater uncertainty, match the cars that are not produced during the lockdown). This, we concede, is more realistic in the manufacturing sector, which produces storable goods. Something similar shall be assumed in the services sector, where a portion of the drop in demand matches the supply-side shock (e.g. accommodation not produced in spring because of the lockdown will be offset by a missing demand at Easter because of the restrictions resulting from measures to maintain social distancing).

We extend our forecast until the end of 2021, considering two alternative scenarios. In the first one, after the supply-side shock in the spring of 2020 and the subsequent demand-side shock, there is a recovery in 2021. In the second scenario, there is a resurgence of the pandemic in the autumn of 2020; so the recovery in 2021 is weaker and slower than in the former scenario.

This forecast is plagued with two sources of uncertainty. For one, COVID-19 is a natural disaster, but unlike earthquakes and floods, it does not destroy public infrastructure or the stock of private fixed capital. Rather, it has simply caused a temporary halt in the economic activity of several sectors. In addition, contrary to the recent Great Recession, the current crisis is not caused by financial difficulties: this is a novel situation, and we lack references that might provide analogies. The situation is evolving rather quickly, and we are missing some data that might inform us of where we are at present. Furthermore, we do not know if there will be another wave of the pandemic in autumn, and neither do we know how agents and firms will react to the shock in the summer in terms of expenditure. It also remains to be seen whether and when we will have a reliable COVID-19 vaccine. For these reasons, all forecasts must be made with care.

\section{The model, some assumptions and a preview of results}

\subsection{The input-output framework}

Initially developed by Leontief as a tool in interindustry analysis (Leontief, 1951), input-output models allow for the analysis of the effects produced in industrial activity by exogenous changes of final demand and by commodity exchanges between economic sectors. Consequently, the advantage of using an input-output framework is the ability to quantify the gain in production due to a demand shock as well as accounting for the links between industries in general equilibrium, thus reproducing spillover effects in the economy. Those advantages make input-output models a suitable tool for economic impact evaluation in different fields of research (see for instance Carrascal Incera, Fernández Fernández \& Pereira López, 2013; Ten Raa, 2017), papers collected in Kurtz, Dietzenbacher \& Lager (1998), and comments in Carter (2000). However, the application of an input-output model must consider the limitations related to the underlying assumptions of this methodology, which mainly include a static structure for each sector of the economy with fixed output ratios and constant return of scale.

Following the traditional definition in Miller \& Blair (2009), the basic balance in an input-output model is determined by the following equation:

$$
\mathbf{x}_{i}=\sum_{j} a_{i j} \cdot \mathbf{x}_{j}+\mathbf{d} \mathbf{f}_{i}
$$


where $x_{i}$ is the total domestic production of sector $i$ of the economy, $a_{i j}$ are the technical production coefficients which represent the input from sector $i$ needed to produce one unit of output in sector $j, x_{j}$ is the total output of sector $j$ of the economy and $\mathbf{d f}_{i}$ is the final demand for product $i$. Equation 1 represents the supply-demand balance in the economy, in which total output of a product is split into the intermediate consumption required by economic sectors and final demand. For an economy with $n$ sectors, the input-output model could be represented in matrix form ${ }^{3}$ :

$$
\mathbf{x}=(\mathbf{I}-\mathbf{A})^{-1} \cdot \mathbf{d f}
$$

with $(\mathbf{I}-\mathbf{A})^{-1}$ being the traditional Leontief matrix where $\mathbf{A}=\left\{\mathbf{a}_{i j}\right\}$ is the $n \times n$ matrix of technical production coefficients that is subtracted from $n \times n$ identity matrix $\mathbf{I}, \mathbf{x}$ is the $n \times 1$ vector of sectoral gross outputs and $\mathbf{d f}$ is the $n \times 1$ vector of total final demand. As such, vector $\mathbf{x}$ in equation (2) comprises both the direct effects by the initial demand shock and the indirect effects due to subsequent supply-chain impacts on other sectors.

In addition to gross output $\mathbf{x}$, the employment $\mathbf{l}$ and value added $\mathbf{v}$ derived from the direct and indirect effects of the final demand shock can be obtained as follows:

$$
\begin{aligned}
& \mathbf{l}=\hat{\mathbf{l}}_{\mathrm{d}} \cdot \mathbf{x}=\hat{\mathbf{l}}_{\mathrm{d}} \cdot(\mathbf{I}-\mathbf{A})^{-1} \cdot \mathbf{d f} \\
& \mathbf{v}=\hat{\mathbf{v}}_{\mathrm{d}} \cdot \mathbf{x}=\hat{\mathbf{v}}_{\mathrm{d}} \cdot(\mathbf{I}-\mathbf{A})^{-1} \cdot \mathbf{d f}
\end{aligned}
$$

where $\hat{\mathbf{l}}_{\mathbf{d}}$ and $\hat{\mathbf{v}}_{\mathrm{d}}$ are $n \times n$ diagonal matrices obtained from $1 \times n$ vectors $\mathbf{l}_{\mathbf{d}}=\frac{\mathbf{l}_{j}}{\mathbf{x}_{j}}$ and $\mathbf{v}_{\mathbf{d}}=\frac{\mathbf{v}_{j}}{\mathbf{x}_{j}}$, which represent the direct coefficients of sectoral employment $\mathbf{l}$ and sectoral value added $\mathbf{v}$ respectively.

\subsection{Modelling the impact of COVID-19 on the Spanish economy}

We base our estimations on Leontief's dynamic model (Leontief, 1986). Within that framework, at the end of period $t$ we obtain total output $\mathbf{x}_{t}$. Consumption $\mathbf{c}_{t}$, exports $\mathbf{e x}_{t}$, and inventories $\mathbf{s}_{t}$ make up the final demand, which is discounted from this vector $\mathbf{x}_{t}$. The remainder of output $\mathbf{x}_{t}$ is to be used as inputs (replacement for what was used as intermediate inputs in period $t$, plus investment) for the next period of production in $t+1$. We assume that all inputs are present at the beginning of each production process, and output is obtained at the end of the corresponding period of time.

\begin{tabular}{|l|l|l|l|l|}
\hline \multicolumn{2}{|c|}{ End of $t$} & Beginning of $t+1$ & End of $t+1$ \\
\hline Output & $\mathbf{x}_{t}$ & & & $\mathbf{x}_{t+1}$ \\
\hline Intermediate inputs & & & $\mathbf{A} \cdot \mathbf{x}_{t+1}$ & \\
\hline Surplus & & $\mathbf{c}_{t}, \mathbf{e x}_{t}, \mathbf{s}_{t}$ & & \\
\hline
\end{tabular}

Figure 1. The model. Source: own elaboration.

\footnotetext{
3 The standard input-output notation is used in this paper. Moreover, matrices are named in bold capital letters, vectors in bold lower-case letters, and scalars in italic lower-case letters. Finally, a hat sign over a vector indicates diagonalization and a prime sign transposition.
} 
Thus:

$$
\begin{gathered}
\mathbf{x}_{t}=\mathbf{c}_{t}+\mathbf{e} \mathbf{x}_{t}+\mathbf{s}_{t}+\mathbf{A} \cdot \mathbf{x}_{t+1} \\
\mathbf{A} \cdot \mathbf{x}_{t+1}=\mathbf{A} \cdot \mathbf{x}_{t}+\mathbf{i}_{t}
\end{gathered}
$$

In (1) we hold that total output equals consumption, exports, inventories (final uses at the end of period $\mathrm{t}$ ) plus intermediate inputs to be used in the next production process, $t+1$.

In (2), intermediate inputs in $t+1$ equal intermediate inputs one period earlier plus investment at the end of period t. A stands for the usual input-output matrix of technical coefficients as previously described and $\mathbf{i}$ is the $n \times 1$ vector of investment.

The input-output table has been initially extracted from the 2016 domestic input-output table for Spain (SIOT) that was published by INE (2016). This table is defined at producer prices and broken down into 64 industries according to NACE Rev. 2 (Statistical classification of economics activities). In order to better harmonize input-output data with final demand components $\mathbf{c}_{t}, \mathbf{e x}_{t}, \mathbf{s}_{t}$ obtained from 2019 records, the 2016 input-output table has been projected to 2019 according to the Euro method described in Eurostat (2014). The basic idea behind this method involves an iterative procedure to derive an input-output table by using the projection of value added by different branches and the various categories of final demand. As indicated by Eurostat, the Euro method has some correspondence to the procedure of Almon (2000) to estimate product-to-product input-output tables from supply and use tables by applying the product-technology assumption.

For the sake of simplicity, although results from the model were obtained for 64 sectors, they have been further aggregated to 15 sectors, which are described in the appendix of this document.

\subsubsection{Supply-side shock}

If some processes have to stop their activity for a while (i.e. several weeks), we will obtain less output in the same proportion, and the inputs that are not used will appear at the end of the process as unplanned additional inventory. The impact of the halt in production at the sectoral level can be measured with the following expression:

$$
\mathbf{v} \mathbf{a}_{d i r}=\widehat{\mathbf{u v a}} \cdot \widehat{\boldsymbol{\alpha}} \cdot \mathbf{x}_{\mathbf{0}}
$$

where $\mathbf{u} \widehat{\mathbf{v a}}$ is a diagonal matrix from the (row) vector of value added per unit of total output, $\mathbf{x}_{\mathbf{0}}$ is a vector of total output that is used as a reference level to measure the impact of COVID-19, and $\widehat{\boldsymbol{\alpha}}$ is a diagonal matrix from the vector of percentages of falling industrial activity. Elements in this matrix are the result of multiplying the percentage activity decrease by the number of weeks during which that drop will take place, and divided by 52 weeks per year.

Furthermore, $\mathbf{v a}_{\text {dir }}$ stands for the vector of direct reductions of sectoral value added due to the lockdown and other measures adopted to contain the spread of the virus.

For $\widehat{\boldsymbol{\alpha}}$ we have used the following basic information encapsulated in Table 1 below, following the criteria used in Banco de España (2020a, 2020d). For instance, we have assumed that the production of motor vehicles closes completely for 4 weeks in the first scenario, as described in ANFAC (2020). In trade we assume that the decrease is $45 \%$ because the food trade and pharmacies were open as usual, though other retail trade businesses were forced to close.

In Scenario 1, the first two weeks are part of the first quarter (the second half of March), and they explain the drop in activity for this period of time, which according to the INE (the Spanish Statistical Office), was $5.2 \%$. The remaining weeks fall within the second quarter. For trade and accommodation, restaurants \& entertainment, we have assumed that the shock lasts until the end of May.

In Scenario 2, it is assumed that there is a second outbreak of COVID-19 in autumn, the fourth quarter of 2020. In that case, the greatest impact is in transport and accommodation, restaurants \& 
entertainment (for the latter industry, we have assumed that it would remain completely closed throughout the entire quarter).

Table 1. Percentage of falling sectoral activity and number of weeks for the supply-side shock

\begin{tabular}{lccc}
\hline & $\%$ fall & $\begin{array}{c}\text { Number of weeks } \\
\text { Scenario 1 }\end{array}$ & $\begin{array}{c}\text { Number of weeks } \\
\text { Scenario } 2\end{array}$ \\
\hline Primary sector & $0 \%$ & - & - \\
Energy & $0 \%$ & - & - \\
Manufacturing & $100 \%$ & 2 & 6 \\
Motor vehicles & $100 \%$ & 4 & 4 \\
Building \& construction & $100 \%$ & 2 & 14 \\
Trade & $45 \%$ & 8 & 17.5 \\
Transportation & $50 \%$ & 10 & 23 \\
Accommodation, restaurants \& entertainment & $100 \%$ & 10 & 4 \\
Other market services & $5 \%$ & 2 & 4 \\
Non-market services & $-5 \%$ & 2 & 4 \\
\hline
\end{tabular}

Note: For non-market services, we have assumed that activity rises by $5 \%$ in the health industry. Sources: ANFAC (2020), Banco de España (2020a, 2020d), Exceltur (2020), and authors' calculations.

With information reported in Table 1 we calculated the coefficients in matrix $\widehat{\boldsymbol{\alpha}}$. Then, using expression (3) above, we obtained an estimation of the direct impact on GDP4 due to the supply-side shock caused by COVID-19, as it is shown in Table 2 below ${ }^{5}$ :

Table 2. Supply-side shock. Direct effect on GDP (2020)

\begin{tabular}{lcc} 
& Scenario 1 & Scenario 2 \\
\hline GDP (yearly effect) & $-3.26 \%$ & $-6.33 \%$ \\
\hline
\end{tabular}

Source: authors' calculations.

In other words, as a consequence of the lockdown and the measures taken to maintain social distancing and low mobility from mid-March to late May, GDP is expected to fall by $3.2 \%$ in 2020, if we take into consideration only the direct effects of those measures. If there is another outbreak of coronavirus in autumn 2020 , GDP will fall by $6.3 \%$.

However, due to existing sectoral interdependence, the shock will spread throughout the entire system: once one sector stops working, it consumes fewer inputs, leading to an increase in unplanned inventories, $\mathbf{A} \cdot \widehat{\boldsymbol{\alpha}} \cdot \mathbf{x}_{\mathbf{0}}$. Assuming that industries have all required inputs at the beginning of their corresponding production processes, if inventories are larger than desired in period $t$, firms will demand fewer inputs for each level of planned output in period $t+1$, thus giving rise to a further fall of

\footnotetext{
4 The relationship between Value Added (VA) and GDP is defined as GDP = VA + Taxes on products - Subsidies on products Despite this well-known difference, the effects on GDP in this paper are measured through changes in value added assuming that value added entails the contribution to GDP made by sectors from the supply side.

${ }^{5}$ In April, the number of people paying into the Social Security system decreased by 883,000 , and the number of workers affected by a temporary labor force adjustment plan amounted to 3.4 million. This means a $22 \%$ reduction in the labor force, according to the Social Security registry, for two months; and for the whole year, it amounts to $3.7 \%$. If we add the 1.4 million self-employed people that applied for the unemployment subsidy, this figure goes up to $4.9 \%$. The figures for laid off workers and self-employed people who stopped working have been taken from Hernández de Cos (2020).
} 
total output and value added. The total effect of the supply-side shock can be measured with the help of the following expression:

$$
\mathbf{v} \mathbf{a}_{T}=\mathbf{v} \mathbf{a}_{d i r}+\widehat{\mathbf{u v a}} \cdot[\mathbf{I}-\mathbf{A}]^{-1} \cdot \mathbf{A} \cdot \widehat{\boldsymbol{\alpha}} \cdot \mathbf{x}_{\mathbf{0}}=\widehat{\mathbf{u v a}} \cdot[\mathbf{I}-\mathbf{A}]^{-1} \cdot \widehat{\boldsymbol{\alpha}} \cdot \mathbf{x}_{\mathbf{0}}
$$

with $(\mathbf{I}-\mathbf{A})^{-1}$ being the traditional Leontief matrix ${ }^{6}$. Vector $\mathbf{v a}_{T}$ describes the direct and indirect consequences of the fall of output on sectoral value added. For our calculations, and for obvious reasons, we shall use the matrix of domestic inputs. Expressions (3) and (4) inform us about the supply-side shock. Table 3 below encapsulates the total supply-side shock on GDP, as from expression (4). The Leontief inverse roughly doubles the direct effect.

Table 3. Supply-side shock. Total effect on GDP (2020)

\begin{tabular}{lcc}
\hline & Scenario 1 & Scenario 2 \\
\hline GDP (yearly effect) & $-5.95 \%$ & $-11.29 \%$ \\
\hline
\end{tabular}

Source: authors' calculations.

\subsubsection{Demand-side shock}

After the drop in value added, agents will react by reducing their spending, thus contributing to a further drop in output through a fall in final demand. As mentioned above, we have singled out three components of final demand: private consumption, investment and exports.

The direct effect of the demand shock on GDP can be measured as follows. We assume the Keynesian principle of effective demand so that, if entrepreneurs forecast a drop in final demand, they will react by reducing production. We measure the direct impact of demand-side shock on total output:

$$
\mathbf{d x}_{D d s}=(\mathbf{d c}+\mathbf{d e x}+\mathbf{d i})
$$

where dc, dex and di stand for the change in private consumption, exports and investment respectively. The (column) vector $\mathbf{d x}_{D d s}$ is the direct change in total output due to the demand-side shock. We have based our forecast on the aggregate projection made by Banco de España (2020a) and Gobierno de España (2020) for each component of final demand as a given (see Tables 4 and 5 below) and then used additional information to estimate results at a disaggregated level in 64 industries in two scenarios, for 2020 and 2021. The procedure for obtaining estimations of consumption, exports and investment is described below.

Data to quantify the change in private consumption dc has been collected from the 2019 microdata of the Spanish Household Budget Survey (HBS) by INE (2019). This database provides information on the amount (in purchaser prices) and the structure of household expenditures according to Classification of Individual Consumption by Purpose (COICOP). These values have been transformed into producer prices by removing value added taxes, trade and transportation margins. It is worth noting there is no official bridge between the classification used in HBS microdata referring to

\footnotetext{
${ }^{6}$ In general, a supply-side shock has forward and backward effects. When a business stops working, the forward effect accounts for the consequences on the industries to which it provides inputs. The backward effect represents the consequences on its own providers as it slows down the demand for input. In this paper, we shall focus only on the backward effects. We shall assume that supply-side effects are negligible, because all missing inputs can be sorted out with existing stocks, or by simply assuming that if the halt in production is not very long, users will offset the temporary lack of input by speeding up production processes once activity resumes. This is an alternative approach to the Ghosh model, which is often used for the analysis of supply-side shocks. For a critical review of the Ghosh model see Miller \& Blair (2009).
} 
commodity expenditures and in the SIOT inter-industry production. Therefore, it has been necessary to allocate these commodities to the industrial scheme adopted by the SIOT to provide comparable results between consumption demand and sectoral production.

A final key feature involves the imports incorporated into household consumption. Imported products cause no productive impact in terms of value added and job generation, so they have been excluded. Considering that the HBS does not provide explicit information about expenditures related to imports, the distinction between domestic and imported products is based upon the corresponding distribution of domestic and imported products for household consumption in the SIOT.

Sectoral estimates for dc have been built upon the consumption projections reported by INE (2019). This report describes the consumption trend evolving from a first period of stagnation to a second period of stabilization where consumption is progressively recovering in 2021to finally reach pre-crisis consumption levels. Retail (-84\%), accommodation and transportation (-95\%), and restaurants (-95\%) -mostly by the limitations on tourism activities- are the most affected industries. As we show below (in Table 11) the drop in consumption is larger for durable consumer goods and also those goods which correspond to "social consumption" (e.g. restaurants, hotels, etcetera). The negative impact on household consumption has been boosted by the combined effect of an increase in savings for precautionary reasons $(10 \%$ according to Deloitte estimations) and a reduction of purchasing power due to the earning shortfalls caused by the supply-side shock (roughly 6\%). We have adapted this reference scenario from the distribution of the consumption basket to the classification of consumption by industry, to further include an additional scenario considering a weaker and slower recovery in 2021.

For exports, we have taken data from the Secretaría de Estado de Comercio (2019) using the Clasificación Nacional de Actividades Económicas (CNAE) 2009. This data base includes only exports of goods. Hence, we complete this information with data provided by the Banco de España, for tourism and other services. There is a small discrepancy between total exports of goods, according to the Secretaría de Estado de Comercio and the Banco de España, amounting, on average, to roughly 1.2\% for the period between 2014 and 2019.

We comment on the size of three sectors regarding Spanish exports: motor vehicles, tourism and other services, accounting for $11.8 \%, 16.4 \%$ and $16.8 \%$, respectively, of total exports in 2019 . Other large industries are: food (6.5\%), chemical industry (6.2\%), agriculture, livestock, and forestry (4.1\%), refining of crude oil (3.5\%) and textile garments (3\%). The first three industries add up to $45 \%$ of total exports. If we aggregate the other sectors, we reach roughly $70 \%$.

In this paper, the aggregate expectation of a negative growth rate $(-16.7 \%)$ in Scenario 1 for exports in 2020, involves assuming a generalized rate of change between $-6 \%$ and $-8 \%$ for all industries. This percentage change is lower in equipment, and higher in intermediate and consumption goods, according to information from the industrial situation survey (Ministerio de Industria, Comercio y Turismo, 2019). To this we add the exception of a negative growth rate of $-20 \%$ for motor vehicles and $-50 \%$ for the tourism industry. In Scenario 2 (an aggregate projection of change of $-21.9 \%$ ), the general fall in exports is assumed to decline between $-8 \%$ and $-10 \%$, and $-25 \%$ and $-70 \%$ for motor vehicles and tourism, respectively. According to the forecasts provided by the Banco de España (2020b), Spain's export markets are expected to grow at $-13.1 \%$. ANFAC (the national association of motor vehicle producers) reports a fall in vehicle exports of, roughly, 25\% over March-September, 2020 (ANFAC, 2020). Moreover, Exceltur (an association of 34 large corporations in the tourism industry) warns of a fall of between $60 \%$ and $80 \%$ of output for subsectors in this industry with respect to 2019 (Exceltur, 2020). These trends evolve in the opposite direction in 2021.

The figures for gross capital formation at the sectoral level (64 industries) have been elaborated using information from the Fundación BBVA and Instituto Valenciano de InvestigacioneS Económicas (IVIE) on the stock of productive net capital in Spain (Fundación BBVA \& IVIE, several years) for 2016. Using that data, which we combine with our own projection of the vector of gross capital formation for 2019, and expectations on the evolution of consumption and exports (which we take as autonomous demand), we produce an estimation of gross investment for 2020 and 2021. 
In the Fundación BBVA and IVIE data base, we find a disaggregation of the stock of net capital for 31 industries, which we reduce to 29 because we do not distinguish between private and public education or healthcare, and for 11 capital goods, of which we take only 8 (we discard software, other material assets and cultivated biological resources). These goods accounted for $62 \%$ of gross investment in 2019.

Gross capital formation is the outcome of adding up three elements: depreciation, net investment, and change in inventories. We obtain a matrix of depreciation by dividing each of the eight rows of the matrix of capital stock by the useful life-time of its corresponding capital good, $\mathbf{T}_{i}$. For each capital good, its depreciation is obtained using the following expression:

$$
\mathbf{D}_{i, t}=\frac{1}{\mathbf{T}_{i}} \sum_{j=1}^{n} \mathbf{K}_{i, j}
$$

For net investment, our own estimations are based on the notion of the accelerator: under the assumption of linear technologies and non-substitutability, we have for each of the eight capital goods, namely $i$, required for the production of one unit of commodity $j$, when using productive capacity at the normal level:

$$
\frac{\mathbf{K}_{i j}}{\mathbf{x}_{j}}=\frac{\Delta \mathbf{K}_{i j}}{\Delta \mathbf{x}_{j}}
$$

where $\mathbf{x}_{j}$ accounts for total output of sector $j$. If we identify $\Delta \mathbf{K}_{i j}$ with net investment of capital good $i$ used by industry $j$, which we shall call $\mathbf{I}_{i, j, t}{ }^{N}$, we have:

$$
\mathbf{I}_{i, j, t}{ }^{N}=\frac{\mathbf{K}_{i j}}{\mathbf{x}_{j}} \cdot \Delta \mathbf{x}_{j}=\frac{\mathbf{K}_{i j}}{\Delta \mathbf{x}_{j}} \cdot \beta_{j} \cdot\left(\Delta \mathbf{c}_{j}+\Delta \mathbf{e x}_{j}\right)_{t}
$$

We have assumed that firms decide how much net investment they will undertake depending on the capital output ratio for each capital good times the expected permanent increase of final autonomous demand, which at the sectoral level includes consumption plus exports. The parameter $\beta_{j}$ stands for the percentage of change in expected autonomous demand for industry $j$ that is considered permanent (we have assumed a range between 0.2 and 0.5 ).

Once we add up all industries $j$ that use capital good $i$, we have the corresponding amount of net investment depending on expected autonomous demand:

$$
\mathbf{I}_{i, t}{ }^{N}=\sum_{j=1}^{n} \frac{\mathbf{K}_{i j}}{\Delta \mathbf{x}_{j}} \cdot \beta_{j} \cdot\left(\Delta \mathbf{c}_{j}+\Delta \mathbf{e x}_{j}\right)_{t}
$$

And for change in inventories, which we shall call $\mathbf{V E}_{i, t}$ we have used the figures obtained from the total effect of the supply-side shock (see section 2.2.1 above).

Hence, for each of the 8 components of the vector of gross capital formation matching the information provided by Fundación BBVA and IVIE, we have applied the following expression:

$$
\mathbf{I}_{i, 2020}=\mathbf{D}_{i, 2020}+\mathbf{I}_{i, 2020}{ }^{N}+\mathbf{V E}_{i, 2020}
$$

For the other components of the gross capital formation vector, we have assumed a rate of growth equal to the expected rate of growth of the remaining final demand.

Table 4 below shows the outcome of expression (5) for years 2020 and 2021, under two different scenarios, breaking down final demand into three components 7 .

\footnotetext{
${ }^{7}$ Muellbauer (2020) estimates a total drop in US consumption of 19.1\% in 2020, which we find too large because it includes, amongst other factors, a $10 \%$ rise in unemployment. Our position is closer to his estimation of a $9 \%$ drop in consumption as this author considers only a drop in income and a decreasing propensity to consume.
} 
Table 4. Demand-side shock. Direct effect on total output

\begin{tabular}{lcccc}
\hline & $\begin{array}{c}\text { Scenario 1 } \\
(2020)\end{array}$ & $\begin{array}{c}\text { Scenario 2 } \\
(2020)\end{array}$ & $\begin{array}{c}\text { Scenario 1 } \\
(2021)\end{array}$ & $\begin{array}{c}\text { Scenario 2 } \\
(2021)\end{array}$ \\
\hline Total output & $-6.4 \%$ & $-8.0 \%$ & $+5.4 \%$ & $+5.6 \%$ \\
Total demand & $-13.8 \%$ & $-17.4 \%$ & $+13.6 \%$ & $+14.6 \%$ \\
Private consumption & $-9.1 \%$ & $-11.2 \%$ & $+9.0 \%$ & $+11.2 \%$ \\
Gross capital formation & $-20.6 \%$ & $-25.1 \%$ & $+9.7 \%$ & $+16.9 \%$ \\
Exports & $-16.7 \%$ & $-21.9 \%$ & $+21.8 \%$ & $+18.5 \%$ \\
\hline
\end{tabular}

Sources: Deloitte (2020) and authors' calculations.

Figures for final demand components are aligned with the forecasts by Banco de España (2020a) and Gobierno de España (2020) that are shown in Table 5.

Table 5. Forecast of final demand. Banco de España and Gobierno de España

\begin{tabular}{llcccc}
\hline & & $\begin{array}{c}\text { Scenario 1 } \\
(2020)\end{array}$ & $\begin{array}{c}\text { Scenario 2 } \\
(2020)\end{array}$ & $\begin{array}{c}\text { Scenario 1 } \\
(2021)\end{array}$ & $\begin{array}{c}\text { Scenario 2 } \\
(2021)\end{array}$ \\
\hline Banco de España & Private consumption & $-9.1 \%$ & $-11.2 \%$ & $+9.0 \%$ & $+11.2 \%$ \\
& Gross capital formation & $-20.6 \%$ & $-26.5 \%$ & $+9.7 \%$ & $+7.4 \%$ \\
& Exports & $-16.7 \%$ & $-21.9 \%$ & $+21.8 \%$ & $+18.5 \%$ \\
& & & & $+4.7 \%$ \\
Gobierno de España & Private consumption & $-8.8 \%$ & & $+16.7 \%$ \\
& Gross capital formation & $-25.5 \%$ & & $+11.6 \%$ \\
\hline
\end{tabular}

Sources: Banco de España (2020a) and Gobierno de España (2020).

Given all of the above, the Leontief inverse will give us the total effect of changing final demand on total output:

$$
\mathbf{d} \mathbf{x}_{T d s}=[\mathbf{I}-\mathbf{A}]^{-1} \cdot(\mathbf{d c}+\mathbf{d e x}+\mathbf{d i})
$$

The (column) vector $\mathbf{d} \mathbf{x}_{T d s}$ is the direct and indirect change of total output due to the demand-side shock, which is shown in Table 6.

Table 6. Demand-side shock. Total effect on output

\begin{tabular}{lcccc}
\hline & $\begin{array}{c}\text { Scenario 1 } \\
(2020)\end{array}$ & $\begin{array}{c}\text { Scenario 2 } \\
(2020)\end{array}$ & $\begin{array}{c}\text { Scenario 1 } \\
(2021)\end{array}$ & $\begin{array}{c}\text { Scenario 2 } \\
(2021)\end{array}$ \\
\hline Total output & $-11.12 \%$ & $-13.98 \%$ & $+9.57 \%$ & $+9.88 \%$ \\
\hline
\end{tabular}

Source: authors' calculations.

Finally, in order to avoid the issue of double counting if we add up the supply-side and demand-side shocks, we shall choose the maximum shock value. If, as a consequence of the supply-side shock, the drop in total output is: 


$$
\mathbf{d} \mathbf{x}_{T S S}=[\mathbf{I}-\mathbf{A}]^{-1} \cdot \widehat{\boldsymbol{\alpha}} \cdot \mathbf{x}_{\mathbf{0}}
$$

then, we should pick the maximum values of the components of the pair $\left\{\mathbf{d x}_{T d s}, \mathbf{d x}_{T s s}\right\}$. We shall call the resulting vector $\mathbf{d} \hat{\mathbf{x}}_{T}{ }^{*}$. By doing so, we are assuming that, for instance, if the motor vehicle sector diminishes its output by $10 \%$ and the demand for cars falls $8 \%$, output only drops by $10 \%$. By and large, in the tourism sector we assume that the demand-side shock will be larger, though in that case we should only take into account the demand shock.

Our forecast of changing GDP due to the impact of COVID-19 at the sectoral level should arise from the following formula:

$$
\mathbf{v a} \mathbf{a}^{*}=\mathbf{u v a} \cdot \mathbf{d} \hat{\mathbf{x}}_{T}{ }^{*}
$$

Table 7. Total effect on GDP

\begin{tabular}{lcccc}
\hline & $\begin{array}{c}\text { Scenario 1 } \\
(2020)\end{array}$ & $\begin{array}{c}\text { Scenario 2 } \\
(2020)\end{array}$ & $\begin{array}{c}\text { Scenario 1 } \\
(2021)\end{array}$ & $\begin{array}{c}\text { Scenario 2 } \\
(2021)\end{array}$ \\
\hline VA/GDP & $-10.20 \%$ & $-12.93 \%$ & $+8.68 \%$ & $+8.96 \%$ \\
\hline
\end{tabular}

Source: authors' calculations.

The reader should note that the figures in Table 7 are larger than in Table 4 because here we have the direct and indirect effect on GDP of changing certain final demand components.

Figure 2 illustrates our estimations.

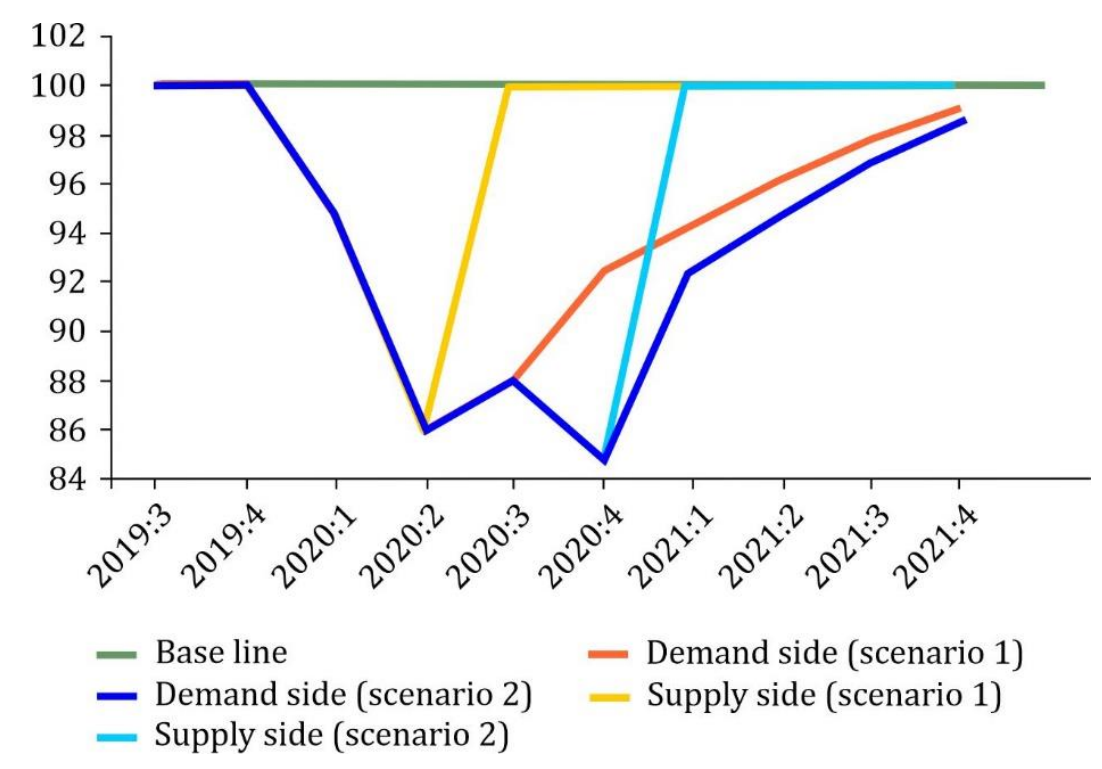

Figure 2. Supply- and demand-side shocks. Scenarios 1 and 2. Spain (2020-2021). Source: authors' calculations.

In both scenarios, the demand-side shock is larger than the supply-side shock; and in Scenario 2 , the recovery is slower, as the loss of output is mostly concentrated in the fourth quarter of 2020. 


\section{Some estimations}

In Table 8 below, we have summed up the estimations made by several institutions as to the impact on the Spanish economy of measures to contain the virus.

Table 8. Some estimations on Spanish GDP due to COVID-19

\begin{tabular}{lcc}
\hline Institution & GDP (\% yearly change) & GDP (\% yearly change) \\
& 2020 & $(2021)$ \\
\hline Banco de España (April 2020) & & $+5.5 \%$ \\
$\quad$ Scenario 1 & $-6.8 \%$ & $+6.1 \%$ \\
Scenario 2 & $-9.5 \%$ & $+8.5 \%$ \\
Scenario 3 & $-12.4 \%$ & \\
& & $+7.7 \%$ \\
Banco de España (June 2020) & & $+9.1 \%$ \\
Scenario 1 (early recovery) & $-9.0 \%$ & $+4.0 \%$ \\
Scenario 2 (slow recoverty) & $-11.6 \%$ & $+6.8 \%$ \\
Scenario 3 (hight risk) & $-15.1 \%$ & $+5.7 \%$ \\
& & $+6.0 \%$ \\
Spanish Government & $-9.2 \%$ & $+7.0 \%$ \\
BBVA Research & $-8.0 \%$ & $+4.3 \%$ \\
Fundación de las Cajas de Ahorros (FUNCAS) & $-8.4 \%$ & \\
European Commission (May 2020) & $-9.4 \%$ & \\
Spanish Chamber of Commerce & $-10.6 \%$ & $+4.6 \%$ \\
& & $+5.8 \%$ \\
AIReF & & \\
$\quad$ Scenario 1 & $-8.9 \%$ & \\
Scenario 2 & $-11.7 \%$ & \\
\hline
\end{tabular}

Note: In mid-May, the Head of the Banco de España discarded the first scenario, made in April 2020: see Hernández de Cos (2020). Sources: Banco de España (2020a, 2020d), Gobierno de España (2020), FUNCAS (2020), European Commission, Spanish Chamber of Commerce and AIReF.

As a general case, we see that there is a high degree of consensus regarding: (i) a significant drop in GDP in 2020, and (ii) an expected rebound in 2021. The reader should also realize that these forecasts are made assuming that authorities adopt some measures of economic policy (i.e. fiscal and monetary measures, other measures affecting the labor market, etcetera), which partially offset the impact of COVID-19 on output.

Our estimations (in Table 6 above) fall within the realm defined by the forecasts of other institutions.

\section{Our forecasts}

The following tables offer a summary view of our forecasts for a disaggregation in 15 sectors $^{8}$. In Table 9, we see the total effect of the supply- and demand-side shocks on GDP, caused by the lockdown and the measures to maintain social distancing and low mobility according to Scenario 1 . The consequences of the supply-side shock are especially marked in motor vehicles, trade, transport and,

8 The estimations have been obtained for 64 sectors according to NACE Rev. 2 (Statistical classification of economic activities) and are available upon request. For the sake of simplicity, results have been aggregated to 15 industries. 
particularly, accommodation and food services. These last three industries are associated with the tourism industry, which is particularly relevant for the Spanish economy.

In 2020, notwithstanding, the total impact of the demand-side shock in Scenario 1 is much larger than the supply-side shock, with the exception of the transport industry (at the aggregate, $9.8 \%$ versus $5.9 \%)$. The explanation rests, to a large extent, on the fact that demand-side shock is extremely notable in exports (for vehicles, accommodation and food services) and in investment (for construction): we have assumed that the drop in income caused by the supply-side shock will lead to a demand shock, where the decision to invest in houses and to make large expenditures on holidays and tourism will be postponed in 2020. These components should increase substantially in 2021 . The reader may realize that, despite the rebound in 2021, motor vehicles and construction are expected to remain markedly below the initial level in late 2019.

Table 10 shows the total effect of the supply- and demand-side shocks on GDP, caused by the lockdown and the measures to maintain social distancing and low mobility according to Scenario 2 . If we consider Scenario 2, there are some differences with respect to Scenario 1. The first is that the total supply effect is substantially larger (11.3\% versus $5.9 \%)$. Secondly, the supply-side shock is larger than the demand-side shock for trade, transport, accommodation and food services, due to a potential second outbreak of COVID-19 in autumn 2020. And thirdly, despite a stronger rebound in 2021 under Scenario 2, the list is longer of sectors whose final level is significantly lower than the base level, including all manufacturing, trade, transport, accommodation and food services.

In Table 11, we show the vectors of change for private consumption, gross capital formation and exports, according to Scenario 1. The largest drop in private consumption and exports is in vehicles, transport, accommodation and food services. Private consumption of professional services falls markedly and trade falls substantially as an export. Table 12 offers information about the demand shock in Scenario 2, which displays a similar pattern as in Scenario 1, although the shock is greater.

Table 9. Total effect on GDP. Combination of supply- and demand-side shocks. Scenario 1

\begin{tabular}{lcccccc}
\hline Scenario 1 & $\begin{array}{c}\text { VA 2019 } \\
\text { Basic prices } \\
\text { pre-crisis }\end{array}$ & $\begin{array}{c}\text { Change supply } \\
\text { shock }\end{array}$ & $\begin{array}{c}\text { Change demand } \\
\text { shock }\end{array}$ & $\begin{array}{c}\text { Total } \\
\text { change } \\
\text { 2020 }\end{array}$ & $\begin{array}{c}\text { Chage demand } \\
\text { shock over }\end{array}$ & $\begin{array}{c}\text { Change } \\
\text { demand shock } \\
\text { over pre-crisis } \\
\text { level } 2021\end{array}$ \\
\hline S01 & & & & & $2020-2021$ \\
S02 & 28.81 & $-4.15 \%$ & $-6.43 \%$ & $-6.43 \%$ & $10.19 \%$ & $3.76 \%$ \\
S03 & 42.17 & $-5.31 \%$ & $-6.24 \%$ & $-6.24 \%$ & $5.77 \%$ & $-0.47 \%$ \\
S04 & 33.14 & $-7.25 \%$ & $-10.69 \%$ & $-10.69 \%$ & $12.74 \%$ & $2.05 \%$ \\
S04a & 95.38 & $-7.83 \%$ & $-12.36 \%$ & $-12.36 \%$ & $10.70 \%$ & $-1.66 \%$ \\
S05 & 12.46 & $-9.93 \%$ & $-20.23 \%$ & $-20.23 \%$ & $14.90 \%$ & $-5.33 \%$ \\
S06 & 65.90 & $-5.55 \%$ & $-19.24 \%$ & $-19.24 \%$ & $10.23 \%$ & $-9.00 \%$ \\
S07 & 143.88 & $-9.29 \%$ & $-8.68 \%$ & $-9.29 \%$ & $9.86 \%$ & $0.57 \%$ \\
S08 & 60.03 & $-17.09 \%$ & $-10.67 \%$ & $-17.09 \%$ & $9.92 \%$ & $-7.17 \%$ \\
S09 & 67.07 & $-19.64 \%$ & $-33.19 \%$ & $-33.19 \%$ & $24.56 \%$ & $-8.64 \%$ \\
S10 & 43.29 & $-2.23 \%$ & $-1.51 \%$ & $-2.23 \%$ & $1.69 \%$ & $-0.54 \%$ \\
S11 & 41.11 & $-3.22 \%$ & $-8.99 \%$ & $-8.99 \%$ & $9.03 \%$ & $0.04 \%$ \\
S12 & 140.72 & $-2.13 \%$ & $-12.08 \%$ & $-12.08 \%$ & $8.86 \%$ & $-3.21 \%$ \\
S13 & 128.50 & $-5.16 \%$ & $-9.99 \%$ & $-9.99 \%$ & $8.87 \%$ & $-1.12 \%$ \\
S14 & 109.16 & $-0.50 \%$ & $-1.30 \%$ & $-1.30 \%$ & $1.32 \%$ & $0.02 \%$ \\
S15 & 73.65 & $-0.09 \%$ & $0.83 \%$ & $0.83 \%$ & $-0.79 \%$ & $0.03 \%$ \\
Total (109 & 56.19 & $-1.47 \%$ & $-11.53 \%$ & $-11.53 \%$ & $10.05 \%$ & $-1.47 \%$ \\
euros and \%) & $1,129.01$ & $-5.95 \%$ & $-10.20 \%$ & $-10.20 \%$ & $8.68 \%$ & $-1.52 \%$ \\
\hline
\end{tabular}

Note: see sectoral classification in Appendix. Source: authors' calculations. 
Table 10. Total effect on GDP. Combination of supply- and demand-side shocks. Scenario 2

\begin{tabular}{lcccccc}
\hline Scenario 2 & $\begin{array}{c}\text { VA 2019 } \\
\text { Basic price } \\
\text { pre-crisis }\end{array}$ & $\begin{array}{c}\text { Change supply } \\
\text { shock }\end{array}$ & $\begin{array}{c}\text { Change demand } \\
\text { shock }\end{array}$ & $\begin{array}{c}\text { Total } \\
\text { change } \\
\text { 2020 }\end{array}$ & $\begin{array}{c}\text { Chage demand } \\
\text { shock over } \\
\text { 2020-2021 }\end{array}$ & $\begin{array}{c}\text { Change } \\
\text { demand shock } \\
\text { over pre-crisis } \\
\text { level } 2021\end{array}$ \\
\hline S01 & & & & & & $0.07 \%$ \\
S02 & 28.81 & $-7.56 \%$ & $-8.45 \%$ & $-8.45 \%$ & $8.51 \%$ & $-5.11 \%$ \\
S03 & 42.17 & $-9.67 \%$ & $-6.99 \%$ & $-9.67 \%$ & $4.56 \%$ & $-1.05 \%$ \\
S04 & 33.14 & $-12.80 \%$ & $-13.44 \%$ & $-13.44 \%$ & $12.39 \%$ & $-4.45 \%$ \\
S04a & 95.38 & $-12.61 \%$ & $-15.29 \%$ & $-15.29 \%$ & $10.84 \%$ & $-10.61 \%$ \\
S05 & 12.46 & $-15.09 \%$ & $-25.26 \%$ & $-25.26 \%$ & $14.65 \%$ & $-8.06 \%$ \\
S06 & 65.90 & $-10.97 \%$ & $-23.40 \%$ & $-23.40 \%$ & $15.33 \%$ & $-7.21 \%$ \\
S07 & 143.88 & $-17.87 \%$ & $-10.35 \%$ & $-17.87 \%$ & $10.66 \%$ & $-20.03 \%$ \\
S08 & 60.03 & $-30.21 \%$ & $-13.63 \%$ & $-30.21 \%$ & $10.18 \%$ & $-20.50 \%$ \\
S09 & 67.07 & $-45.02 \%$ & $-42.51 \%$ & $-45.02 \%$ & $24.53 \%$ & $-1.18 \%$ \\
S10 & 43.29 & $-4.03 \%$ & $-3.46 \%$ & $-4.03 \%$ & $2.85 \%$ & $-0.77 \%$ \\
S11 & 41.11 & $-5.84 \%$ & $-10.98 \%$ & $-10.98 \%$ & $10.21 \%$ & $-9.37 \%$ \\
S12 & 140.72 & $-4.06 \%$ & $-16.38 \%$ & $-16.38 \%$ & $7.01 \%$ & $-2.94 \%$ \\
S13 & 128.50 & $-9.44 \%$ & $-12.57 \%$ & $-12.57 \%$ & $9.63 \%$ & $-0.02 \%$ \\
S14 & 109.16 & $-0.01 \%$ & $-1.61 \%$ & $-1.61 \%$ & $1.60 \%$ & $-0.01 \%$ \\
S15 & 73.65 & $-0.29 \%$ & $1.22 \%$ & $1.22 \%$ & $-1.23 \%$ & $-4.59 \%$ \\
Total (10 & 56.19 & $-2.63 \%$ & $-15.03 \%$ & $-15.03 \%$ & $10.45 \%$ & $-3.96 \%$ \\
euros and \%) & $1,129.01$ & $-11.29 \%$ & $-12.93 \%$ & $-12.93 \%$ & $8.96 \%$ & \\
\hline
\end{tabular}

Note: see sectoral classification in Appendix. Source: authors' calculations.

Table 11. Final demand shock. Private consumption, gross capital formation and exports. Scenario 1

\begin{tabular}{|c|c|c|c|c|c|c|c|c|}
\hline \multirow[t]{2}{*}{ Scenario 1} & \multicolumn{2}{|c|}{$\begin{array}{c}\text { Private } \\
\text { consumption }\end{array}$} & \multicolumn{2}{|c|}{$\begin{array}{l}\text { Gross capital } \\
\text { formation }\end{array}$} & \multicolumn{2}{|c|}{ Exports } & \multicolumn{2}{|c|}{$\begin{array}{l}\text { Demand } \\
\text { shock }\end{array}$} \\
\hline & 2020 & 2021 & 2020 & 2021 & 2020 & 2021 & 2020 & 2021 \\
\hline S01 & $-1.1 \%$ & $2.3 \%$ & $-9.9 \%$ & $8.2 \%$ & $-4.3 \%$ & $14.7 \%$ & $-3.4 \%$ & $8.9 \%$ \\
\hline S02 & $5.2 \%$ & $-4.7 \%$ & $-8.0 \%$ & $-12.7 \%$ & $-9.1 \%$ & $13.8 \%$ & $2.6 \%$ & $-1.7 \%$ \\
\hline S03 & $-6.0 \%$ & $6.6 \%$ & $-4.8 \%$ & $5.2 \%$ & $-9.1 \%$ & $19.3 \%$ & $-7.2 \%$ & $11.4 \%$ \\
\hline S04 & $-7.5 \%$ & $7.9 \%$ & $-27.6 \%$ & $2.8 \%$ & $-11.1 \%$ & $16.4 \%$ & $-13.2 \%$ & $12.6 \%$ \\
\hline So4a & $-19.7 \%$ & $21.2 \%$ & $-26.9 \%$ & $6.8 \%$ & $-19.5 \%$ & $22.8 \%$ & $-21.0 \%$ & $19.5 \%$ \\
\hline S05 & $-8.0 \%$ & $9.3 \%$ & $-28.6 \%$ & $19.6 \%$ & $0.0 \%$ & $0.0 \%$ & $-27.0 \%$ & $18.6 \%$ \\
\hline S06 & $-5.9 \%$ & $7.2 \%$ & $-4.9 \%$ & $6.3 \%$ & $-9.8 \%$ & $18.7 \%$ & $-7.3 \%$ & $11.3 \%$ \\
\hline S07 & $-13.7 \%$ & $14.9 \%$ & $-8.0 \%$ & $7.0 \%$ & $-31.4 \%$ & $36.4 \%$ & $-19.4 \%$ & $20.8 \%$ \\
\hline S08 & $-26.2 \%$ & $27.7 \%$ & $0.0 \%$ & $0.0 \%$ & $-49.9 \%$ & $63.8 \%$ & $-30.9 \%$ & $32.9 \%$ \\
\hline S09 & $12.3 \%$ & $-12.5 \%$ & $-3.0 \%$ & $4.8 \%$ & $-9.7 \%$ & $18.2 \%$ & $1.4 \%$ & $0.0 \%$ \\
\hline S10 & $-9.0 \%$ & $10.4 \%$ & $0.0 \%$ & $0.0 \%$ & $-9.8 \%$ & $18.7 \%$ & $-9.1 \%$ & $11.4 \%$ \\
\hline S11 & $-8.0 \%$ & $9.4 \%$ & $-6.0 \%$ & $7.0 \%$ & $-49.9 \%$ & $63.8 \%$ & $-30.2 \%$ & $30.0 \%$ \\
\hline S12 & $-19.9 \%$ & $20.6 \%$ & $-6.4 \%$ & $5.6 \%$ & $-20.4 \%$ & $26.1 \%$ & $-14.2 \%$ & $14.8 \%$ \\
\hline S13 & $-7.7 \%$ & $9.0 \%$ & $0.0 \%$ & $0.0 \%$ & $-9.8 \%$ & $18.7 \%$ & $-7.7 \%$ & $9.3 \%$ \\
\hline S14 & $4.8 \%$ & $-4.3 \%$ & $0.0 \%$ & $0.0 \%$ & $-9.8 \%$ & $18.7 \%$ & $4.8 \%$ & $-4.3 \%$ \\
\hline S15 & $-8.5 \%$ & $9.8 \%$ & $-6.0 \%$ & $8.0 \%$ & $-49.1 \%$ & $62.1 \%$ & $-14.2 \%$ & $14.2 \%$ \\
\hline Total & $-9.1 \%$ & $9.0 \%$ & $-20.6 \%$ & $9.7 \%$ & $-16.7 \%$ & $21.8 \%$ & $-13.8 \%$ & $13.6 \%$ \\
\hline
\end{tabular}

Note: see sectoral classification in Appendix. Source: authors' calculations. 
Table 12. Final demand shock. Private consumption, gross capital formation and exports. Scenario 2

\begin{tabular}{|c|c|c|c|c|c|c|c|c|}
\hline \multirow[t]{2}{*}{ Scenario 2} & \multicolumn{2}{|c|}{$\begin{array}{c}\text { Private } \\
\text { consumption }\end{array}$} & \multicolumn{2}{|c|}{$\begin{array}{l}\text { Gross capital } \\
\text { formation }\end{array}$} & \multicolumn{2}{|c|}{ Exports } & \multicolumn{2}{|c|}{$\begin{array}{c}\text { Demand } \\
\text { shock }\end{array}$} \\
\hline & 2020 & 2021 & 2020 & 2021 & 2020 & 2021 & 2020 & 2021 \\
\hline S01 & $0.3 \%$ & $1.9 \%$ & $-11.8 \%$ & $11.8 \%$ & $-8.9 \%$ & $10.1 \%$ & $-5.3 \%$ & $6.6 \%$ \\
\hline S02 & $9.5 \%$ & $-8.9 \%$ & $-10.0 \%$ & $-12.7 \%$ & $-11.0 \%$ & $13.1 \%$ & $5.8 \%$ & $-5.5 \%$ \\
\hline S03 & $-7.5 \%$ & $7.9 \%$ & $-6.8 \%$ & $5.2 \%$ & $-11.3 \%$ & $16.9 \%$ & $-8.9 \%$ & $11.2 \%$ \\
\hline S04 & $-9.2 \%$ & $9.9 \%$ & $-32.8 \%$ & $9.9 \%$ & $-14.1 \%$ & $14.3 \%$ & $-16.2 \%$ & $12.7 \%$ \\
\hline SO4a & $-25.1 \%$ & $27.7 \%$ & $-32.9 \%$ & $22.7 \%$ & $-24.6 \%$ & $18.5 \%$ & $-26.3 \%$ & $20.9 \%$ \\
\hline S05 & $-9.9 \%$ & $12.2 \%$ & $-34.6 \%$ & $34.1 \%$ & $0.0 \%$ & $0.0 \%$ & $-32.7 \%$ & $31.8 \%$ \\
\hline S06 & $-7.2 \%$ & $9.4 \%$ & $-6.9 \%$ & $6.3 \%$ & $-10.0 \%$ & $19.5 \%$ & $-8.2 \%$ & $12.9 \%$ \\
\hline S07 & $-18.2 \%$ & $20.4 \%$ & $-10.0 \%$ & $7.0 \%$ & $-42.2 \%$ & $31.1 \%$ & $-26.0 \%$ & $23.0 \%$ \\
\hline S08 & $-32.1 \%$ & $34.9 \%$ & $0.0 \%$ & $0.0 \%$ & $-70.0 \%$ & $61.1 \%$ & $-39.6 \%$ & $37.5 \%$ \\
\hline S09 & $10.0 \%$ & $-9.3 \%$ & $-5.4 \%$ & $4.8 \%$ & $-10.0 \%$ & $19.1 \%$ & $-0.5 \%$ & $1.5 \%$ \\
\hline S10 & $-10.9 \%$ & $13.3 \%$ & $0.0 \%$ & $0.0 \%$ & $-10.0 \%$ & $19.5 \%$ & $-10.8 \%$ & $14.0 \%$ \\
\hline S11 & $-9.9 \%$ & $12.3 \%$ & $-8.0 \%$ & $7.0 \%$ & $-70.0 \%$ & $61.1 \%$ & $-41.7 \%$ & $25.2 \%$ \\
\hline S12 & $-24.5 \%$ & $25.8 \%$ & $-8.4 \%$ & $9.3 \%$ & $-25.7 \%$ & $23.9 \%$ & $-17.8 \%$ & $17.5 \%$ \\
\hline S13 & $-9.4 \%$ & $11.8 \%$ & $0.0 \%$ & $0.0 \%$ & $-10.0 \%$ & $19.5 \%$ & $-9.5 \%$ & $12.0 \%$ \\
\hline S14 & $6.8 \%$ & $-5.9 \%$ & $0.0 \%$ & $0.0 \%$ & $-10.0 \%$ & $19.5 \%$ & $6.7 \%$ & $-5.9 \%$ \\
\hline S15 & $-10.5 \%$ & $12.9 \%$ & $-8.0 \%$ & $9.5 \%$ & $-68.7 \%$ & $58.4 \%$ & $-18.7 \%$ & $15.3 \%$ \\
\hline Total & $-11.2 \%$ & $11.2 \%$ & $-25.1 \%$ & $16.9 \%$ & $-21.9 \%$ & $18.5 \%$ & $-17.4 \%$ & $14.6 \%$ \\
\hline
\end{tabular}

Note: see sectoral classification in Appendix. Source: authors' calculations.

Finally, regarding labor, the evolution is similar to output, with the most notable losses of employment in accommodation, food services and motor vehicles. We have made our calculations on full-time equivalents. As Table 13 shows, under the hypothesis that temporary and full-time workers experience a similar shock, the rate of unemployment could rise as high as $25.29 \%$ in Scenario 2 (23\% in Scenario 1). By the end of 2021, the rate of unemployment would be $17.91 \%$ according to Scenario 2 (16.12\% in Scenario 1).

Table 13. Labor. Full-time equivalents (in thousands and percentage of variation)

\begin{tabular}{llccccc}
\hline & & \multicolumn{2}{c}{ Scenario 1} & & \multicolumn{2}{c}{ Scenario 2} \\
\cline { 3 - 4 } \cline { 6 - 7 } & 2019 & 2020 & 2021 & & 2020 & 2021 \\
\hline S01 & 653.8 & $-6.39 \%$ & $10.16 \%$ & & $-8.39 \%$ & $8.47 \%$ \\
S02 & 192.6 & $-8.51 \%$ & $8.33 \%$ & & $-10.46 \%$ & $8.87 \%$ \\
S03 & 385.4 & $-11.26 \%$ & $13.33 \%$ & & $-14.27 \%$ & $13.09 \%$ \\
S04 & $1,107.0$ & $-12.14 \%$ & $10.26 \%$ & & $-15.08 \%$ & $10.68 \%$ \\
S04a & 100.2 & $-19.98 \%$ & $14.78 \%$ & & $-24.99 \%$ & $14.66 \%$ \\
S05 & $1,242.6$ & $-19.24 \%$ & $10.23 \%$ & & $-23.40 \%$ & $15.33 \%$ \\
S06 & $3,171.6$ & $-9.25 \%$ & $9.85 \%$ & & $-10.35 \%$ & $10.65 \%$ \\
S07 & 854.1 & $-16.76 \%$ & $10.06 \%$ & & $-16.76 \%$ & $10.37 \%$ \\
S08 & $1,355.8$ & $-33.19 \%$ & $24.56 \%$ & & $-42.51 \%$ & $24.53 \%$ \\
S09 & 465.3 & $-4.18 \%$ & $5.80 \%$ & & $-5.81 \%$ & $6.31 \%$ \\
S10 & 339.4 & $-9.06 \%$ & $9.16 \%$ & & $-11.06 \%$ & $10.39 \%$ \\
S11 & 247.7 & $-33.20 \%$ & $24.36 \%$ & & $-45.04 \%$ & $19.28 \%$ \\
S12 & $2,957.3$ & $-9.78 \%$ & $8.94 \%$ & & $-12.21 \%$ & $9.60 \%$ \\
S13 & $2,584.6$ & $-1.17 \%$ & $1.18 \%$ & & $-1.45 \%$ & $1.42 \%$ \\
S14 & $1,417.1$ & $0.18 \%$ & $-0.13 \%$ & & $0.40 \%$ & $-0.36 \%$ \\
S15 & $1,402.7$ & $-10.20 \%$ & $9.46 \%$ & & $-13.07 \%$ & $10.59 \%$ \\
Total & $18,376.9$ & $-10.27 \%$ & $8.98 \%$ & & $-12.89 \%$ & $9.62 \%$ \\
\hline
\end{tabular}

Note: see sectoral classification in Appendix. Source: authors' calculations. 


\section{Economic policy measures to fight the consequences of COVID-19}

As noted in the introductory section, the shocks caused by COVID-19 have occurred in the context of a lower rate of growth, lower inflation, very low interest rates, and high indebtedness, amongst other facts. Several economic authorities throughout the world have reacted to the pandemic by adopting two types of economic policy measures. On the one hand, they have provided (and continue to provide) some financial assistance to protect vulnerable firms and workers in their respective jurisdictions (Blanchard et al., 2020). In essence, such assistance has consisted in the payment of a fraction of the payroll costs of employees, with a view to making it possible for firms to retain part of their workforce, and guaranteed loans to firms (in some cases also tax deferrals and equity injections) to prevent liquidity and solvency problems once proceeds had plummeted during the lockdown and some expenses had to be settled. Such aid seems to be particularly appropriate in the motor vehicle, transport, and accommodation and food services sectors: large industries in the Spanish economy, with a significant portion of output going to export markets.

Whilst these supply-side measures aim to minimize hysteresis effects once the pandemic is over, they need to be complemented with demand-side economic policy decisions, with a double purpose. Firstly, and chiefly in the short run, they should aim to offset the fall of aggregate expenditure after the supply-side shock (mainly in private consumption because of a higher household rate of saving and also weaker exports and investment). Secondly, they should foster investment in new processes and activities thus positively contributing to a structural change in the production system, particularly those connected to an increase in the efficiency in the use of clean energy sources, digitalization processes, and the improvement of educational skills. This second group of measures should help to re-absorb part of the workforce that will not be able to return to their former jobs (with trade being a clear example of this problem). Such an effort is even more necessary if the rebound that is expected in 2021 is not strong enough to recover from the losses that will take place in 2020. As Blanchard et al. (2020) put it, protection should be combined with reallocation. In this sense, an expansive fiscal policy combined with massive purchases of public debt by central banks is seen as an adequate response to the current crisis. This argument is behind the Recovery and Resilience Facility, in the frame of the Next Generation EU Programme of the European Commission (for an overview, see for instance Banco de España (2020c) and the ECB’s Pandemic Emergency Purchase Programme (European Central Bank, 2020).

\section{Summary and main conclusions}

In this paper, we use input-output techniques to offer an estimation of the impact of measures to stem the COVID-19 pandemic on the Spanish economy at a disaggregate level on activity and employment. Initially, there is a supply-side shock as a consequence of maintaining social distancing, reducing mobility and halting non-essential activity for two weeks. This supply-side shock is expected to give rise to a demand-side shock, which according to our estimations will be far greater, causing more damage to the Spanish economy than the initial shock. 2021 will see some recovery, although the final numbers for GDP and employment are expected to be lower than at the end of 2019.

We have defined two scenarios. In the first one, with regard to supply-side shock, there is only one period of time during which the impact of the virus is relevant, spanning from mid-March to the end of May. In the second scenario, there is a second outbreak of infection in autumn 2020. The demand-side shock is conditioned on the supply-side shock.

In our forecast, we have not made any explicit assumptions about the impact of economic policy measures on GDP and employment.

Table 14 summarizes our main results.

The motor vehicle, trade, transport, and accommodation and food services sectors are the most affected by the shock. The demand shock in 2020 is larger for motor vehicles and accommodation and 
food services, whilst for transport and trade, the largest impact comes from the supply-side shock during the lockdown of March and April. Under the hypothesis of a second wave of contagion in autumn, the supply-side shock is also larger in accommodation and food services (while the fall of demand is larger in the rest of industries). All of these industries carry a large weight in the export sector and, setting aside vehicles, small- and medium-size firms make up the majority in their respective industries. These aspects justify the provision of some public help to these industries; meanwhile, an expansive fiscal policy (combined with a massive purchase of public debt) would prevent a generalized fall in output and employment.

Table 14. Main results

\begin{tabular}{lccccc} 
& \multicolumn{2}{c}{ Scenario 1} & & \multicolumn{2}{c}{ Scenario 2} \\
\cline { 2 - 3 } \cline { 5 - 6 } & 2020 & 2021 & & 2020 & 2021 \\
\hline GDP & $-10.2 \%$ & $+8.7 \%$ & & $-12.9 \%$ & $+9.0 \%$ \\
Private consumption & $-9.1 \%$ & $+9.0 \%$ & & $-11.2 \%$ & $+11.2 \%$ \\
Gross capital formation & $-20.6 \%$ & $+9.8 \%$ & & $-25.1 \%$ & $+16.8 \%$ \\
Exports & $-16.7 \%$ & $+21.8 \%$ & & $-21.9 \%$ & $+18.5 \%$ \\
Employment & $-10.3 \%$ & $+9.0 \%$ & & $-12.9 \%$ & $+9.6 \%$ \\
\hline
\end{tabular}

Note: expenditure also includes imports. Source: authors' calculations.

We conclude this research with a word of caution. There are two sources of uncertainty regarding the estimation of the impact of COVID-19 on the Spanish economy: firstly, until we have a vaccine to keep the infection under control, we cannot know how the pandemic will evolve; and secondly, we do not know exactly how agents will react to the present situation. These facts condition, to a large extent, the validity of the forecasts that we present in this paper.

\section{Appendix}

Sectoral estimations have been obtained for 64 branches according to NACE Rev. 2 (Statistical classification of economic activities). For the sake of simplicity, results have been further aggregated to 15 sectors according to the next classification:

S01 Agriculture, forestry and fishing.

S02 Mining and quarrying; electricity, gas, steam and air conditioning supply; water collection, treatment and supply and waste collection.

S03 Food products, beverages and tobacco products, textiles, clothing and leather products.

S04 Manufacturing.

S04a Motor vehicles and other transport equipment included in S04.

S05 Construction.

S06 Wholesale and retail trade.

S07 Transportation.

S08 Accommodation and food service activities.

S09 Information and communication.

S10 Financial and insurance activities.

S11 Real estate activities.

S12 Professional, scientific and technical activities; administrative and support service activities.

S13 Public administration, defence; education.

S14 Health services and social work activities.

S15 Arts, entertainment and recreation; other service activities; activities of household and extra-territorial organizations and bodies. 


\section{References}

Almon, C. (2000). Product-to-product tables via product-technology with no negative flows. Economic Systems Research, 12(1), 27-43. Retrieved from: https://doi.org/10.1080/095353100111263

ANFAC. (2020). La producción de vehículos en abril cae a mínimos históricos por el cierre total. Madrid: Asociación Española de Fabricantes de Automóviles y Camiones. Retrieved from: https://anfac.com/actualidad/laproduccion-de-vehiculos-en-abril-cae-a-minimos-historicos-por-el-cierre-total/

Baldwin, R. E. (2020). Covid, hysteresis, and the future of work. Global Challenges - Graduate Institute of International and Development Studies. Special Issue 1, Article 15. Geneva, Switzerland: The Graduate Institute of International and Development Studies.

Retrieved from: https://globalchallenges.ch/issue/special 1/covid-hysteresis-and-the-future-of-work/

Banco de España. (2020a). Escenarios macroeconómicos de referencia para la economía española tras el Covid-19. Boletín Económico, 2/2020, 1-35.

Retrieved from: https://www.bde.es/f/webbde/GAP/Secciones/SalaPrensa/COVID-19/be2002-art1.pdf

Banco de España. (2020b). Escenarios macroeconómicos de referencia para la economía española tras el Covid-19. Boletín Económico, 3/2020, 75-76. Retrieved from:

https://www.bde.es/bde/es/secciones/informes/boletines/Boletin_economic/index2020.html

Banco de España. (2020c). Next Generation EU: Principales características e impacto de su anuncio sobre las condiciones financieras. Boletín Económico, 3/2020, 39-41. Retrieved from:

https://www.bde.es/f/webbde/SES/Secciones/Publicaciones/InformesBoletinesRevistas/BoletinEconomico /Informe\%20trimestral/20/Recuadros/Fich/IT-3T20-Rec5-Av.pdf

Banco de España. (2020d). Proyecciones macroeconómicas de la economía española (2020-2022): contribución del Banco de España al ejercicio conjunto de proyecciones del Eurosistema de junio de 2020. Informes de Proyecciones de la Economía Española, junio 2020. Madrid: Banco de España. Retrieved from: https://www.bde.es/f/webbde/SES/AnalisisEconomico/AnalisisEconomico/ProyeccionesMacroeconomicas /ficheros/be08062020-proy.pdf

Blanchard, O., Philippon, T., \& Pisani-Ferry, J. (2020). A new policy toolkit is needed as countries exit COVID-19 lockdowns. Peterson Institute for International Economics Policy Brief, 20-8. Washington, DC: Peterson Institute for International Economics (PIEE).

Retrieved from: https://www.piie.com/system/files/documents/pb20-8.pdf

Bortis, H., \& Heinrich, B. (1997). Institutions, behaviour and economic theory: A contribution to classical-Keynesian political economy. Cambridge, UK: Cambridge University Press. DOI: https://doi.org/10.1017/CBO9780511582349

Carrascal Incera, A., Fernández Fernández, M., \& Pereira López, X. (2013). Waste generation from inbound tourism in Galicia. Revista Galega de Economía, 22(1), 31-50. DOI: https://doi.org/10.15304/rge.22.1.1267

Carter, A. P. (2000). Book review. Economic Systems Research, 12(1), 131-133. DOI: https://doi.org/10.1080/095353100111326

de-Juan, O. (2005). Paths of accumulation and growth: Towards a Keynesian long-period theory of output. Review of Political Economy, 17(2), 231-252. DOI: https://doi.org/10.1080/09538250500067270

Deloitte. (2020). COVID-19. Impacto y escenarios de recuperación en consumo y distribución. Madrid: Deloitte.

European Central Bank. (2020). Pandemic emergency purchase programme (PEPP). Frankfurt, Germany: European Central Bank.

Retrieved from: https://www.ecb.europa.eu/mopo/implement/pepp/html/index.en.html

Eurostat. (2014). Eurostat manual of supply, use and input-output tables. Luxembourg, Luxembourg: Office for Official Publications of the European Communities. Retrieved from:

https://ec.europa.eu/eurostat/documents/3859598/5902113/KS-RA-07-013-EN.PDF/b0b3d71e-39304442-94be-70b36cea9b39

Exceltur. (2020). Impacto coronavirus. Madrid: Exceltur Alianza Turística. Retrieved from: https://www.exceltur.org/wp-content/uploads/2020/04/Impacto-Coronavirus-EXCELTURterritorializados-20200331.pdf

FUNCAS. (2020). Panel de previsiones de la economía española. Madrid: Fundación de las Cajas de Ahorros. Retrieved from: https://www.funcas.es/coyuntura-economica/espana/panel-de-previsiones/panel-de-previsiones/

Fundación BBVA, \& IVIE. (several years). El stock y los servicios del capital en España y su distribución territorial y sectorial (1964-2016). Bilbao: Fundación BBVA/Valencia: Instituto Valenciano de Investigaciones Económicas. Retrieved from: https://www.fbbva.es/microsites/stock09/fbbva stock08 index.html 
Gobierno de España. (2020). Actualización del Programa de Estabilidad 2020. Reino de España. Madrid: Gobierno de España. Retrieved from:

https://www.hacienda.gob.es/CDI/Programas\%20de\%20Estabilidad/Programa_de_Estabilidad 20202021.pdf

Gordon, R. J. (2016). Perspectives on the rise and fall of American growth. American Economic Review, 106(5), 72-76.

Hernández de Cos, P. (2020). La economía española ante la crisis del Covid-19. Comparecencia ante la Comisión de Asuntos Económicos y Transformación Digital del Congreso de los Diputados, 18 de mayo de 2020. Documentos Ocasionales, $n^{\circ}$ 2023. Madrid: Banco de España. Retrieved from: https://www.bde.es/f/webbde/SES/Secciones/Publicaciones/PublicacionesSeriadas/DocumentosOcasional es/20/Fich/do2023.pdf

IMF. (2020a). Spain: 2020 Article IV Consultation-Press Release; Staff Report; and Statement by the Executive Director for Spain. Washington, DC: International Monetary Fund. Retrieved from: https://www.imf.org/en/Publications/CR/Issues/2020/11/12/Spain-2020-Article-IV-Consultation-PressRelease-Staff-Report-and-Statement-by-the-Executive-49883

IMF. (2020b). World Economic Outlook Reports. Washington, DC: International Monetary Fund. Retrieved from: https://www.imf.org/en/Publications/WEO

INE. (2016). Contabilidad nacional anual de España: tablas input-output. Resultados. Madrid: Instituto Nacional de Estadística. Retrieved from:

https://www.ine.es/dyngs/INEbase/es/operacion.htm?c=Estadistica C\&cid=1254736177058\&menu=result ados\&idp=1254735576581

INE. (2019). Encuesta de presupuestos familiares. Madrid: Instituto Nacional de Estadística. Retrieved from: https://www.ine.es/dyngs/INEbase/es/operacion.htm?c=Estadistica C\&cid=1254736176806\&menu=result ados\&idp=1254735976608\#!tabs-1254736195147

Kurtz, H., Dietzenbacher, E., \& Lager, C. (1998). Input-output analysis, vols. I-III. Cheltenham, UK: Edward Elgar.

Leontief, W. (1951). The structure of the American economy. New York, NY: Oxford University Press.

Leontief, W. (1986). Input-output economics. New York, NY: Oxford University Press.

Miller, R. E., \& Blair, P. D. (2009). Input-output analysis: foundations and extensions. Cambridge, UK: Cambridge University Press.

Ministerio de Industria, Comercio y Turismo. (2019). Encuesta de coyuntura industrial e inversiones industriales. Madrid: Ministerio de Industria, Comercio y Turismo.

Retrieved from: https://industria.gob.es/es-es/estadisticas/Paginas/encuesta-coyuntura.aspx

Muellbauer, J. (2020). The coronavirus pandemic and US consumption. VoxEU. org, 11. Retrieved from: https://voxeu.org/article/coronavirus-pandemic-and-us-consumption

Real Decreto 463/2020, de 14 de marzo, por el que se declara el estado de alarma para la gestión de la situación de crisis sanitaria ocasionada por el COVID-19. Legislación consolidada. Ministerio de la Presidencia, Relaciones con las Cortes y Memoria Democrática. Boletín Oficial del Estado, 67, de 14 de marzo de 2020. Referencia: BOE-A-2020-3692. Retrieved from: https://boe.es/buscar/act.php?id=BOE-A-2020-3692

Real Decreto-Ley 10/2020, de 29 de marzo, por el que se regula un permiso retribuido recuperable para las personas trabajadoras por cuenta ajena que no presten servicios esenciales, con el fin de reducir la movilidad de la población en el contexto de la lucha contra el COVID-19. Legislación consolidada. Jefatura del Estado. Boletín Oficial del Estado, 87, de 29 de marzo de 2020. Referencia: BOE-A-2020-4166. Retrieved from: https://www.boe.es/buscar/act.php?id=BOE-A-2020-4166

Secretaría de Estado de Comercio. (2019). DataComex. Estadísticas de Comercio Exterior. Madrid: Ministerio de Industria, Comercio y Turismo. Secretaría de Estado de Comercio.

Retrieved from: https://comercio.serviciosmin.gob.es/Datacomex/

Serrano, F. (1995). Long period effective demand and the Sraffian supermultiplier. Contributions to Political Economy, 14(1), 67-90. DOI: https://doi.org/10.1093/oxfordjournals.cpe.a035642

Summers, L. H. (2014). US economic prospects: Secular stagnation, hysteresis, and the zero lower bound. Business Economics, 49(2), 65-73. Retrieved from:

http://larrysummers.com/wp-content/uploads/2014/06/NABE-speech-Lawrence-H.-Summers1.pdf

Ten Raa, T. (2017). Handbook of input-output analysis. Cheltenham, UK: Edward Elgar.

WHO. (2020). Coronavirus disease (COVID-19). Geneva, Switzerland: World Health Organization. 